\title{
Induction of defense mechanisms in seedlings of oilseed winter rape inoculated with Phoma lingam (Leptosphaeria maculans)
}

\author{
Katarzyna Hura • Tomasz Hura • Renata Bączek-Kwinta • \\ Maciej Grzesiak • Agnieszka Plażek
}

Received: 8 March 2013 / Accepted: 16 August 2013 /Published online: 8 September 2013

(C) The Author(s) 2013. This article is published with open access at Springerlink.com

\begin{abstract}
The aim of this study was to find the biochemical markers of blackleg, evoked by the fungus Leptosphaeria maculans in seedlings of oilseed winter rape. Analyses of antioxidant enzymes activity and reactive oxygen species detection were performed 24 , 48 and $72 \mathrm{~h}$ after inoculation. Moreover, measurements of the total pool of phenolic compounds, transcinnamic acid and ferulic acid were carried out. The results proved the virulence of $\mathrm{Ph}$ L5 isolate towards the rape seedlings. An increase in total phenolic content, including trans-cinnamic acid, was observed $24 \mathrm{~h}$ after inoculation. High activity of phenylalanine ammonia-lyase is probably another symptom of the defense mechanisms, despite the fact that it was not accompanied by elevated phenolics level, which were probably rapidly exhausted during Phoma lingam inoculation. A drop in phenolics content was balanced by higher activity of SOD, CAT and non-specific peroxidases. Enhanced activity of these enzymes was a response to the reactive oxygen species overproduction. ROS accumulation in indirectly inoculated first true leaves after inoculation may suggest a systemic defense response.
\end{abstract}

K. Hura $(\bowtie) \cdot$ R. Bączek-Kwinta $\cdot$ A. Płażek

Department of Plant Physiology, Faculty of Agriculture and Economics, Agricultural University, 30-239 Kraków, Poland e-mail: rrhura@cyf-kr.edu.pl

T. Hura $\cdot$ M. Grzesiak

The Franciszek Górski Institute of Plant Physiology,

Polish Academy of Sciences, 30-239 Kraków, Poland
Keywords Antioxidative enzymes $\cdot$ Phenolics $\cdot$ Reactive oxygen species

\section{Introduction}

Oilseed winter rape is exposed to diseases caused by fungal infections during its entire growth period. Nowadays, when the rape crops acreage is constantly being enlarged to grow plants used for biofuel production, this problem is becoming even more important. Moreover, oilseed rape cultivation tends toward limitation of pesticide usage, with the added benefits of increased environmental protection and quality of food based on rape-seed oil. Therefore, in many countries, improving the resistance of oilseed winter rape against pathogenic fungi becomes a vital issue.

Stem canker (blackleg) caused by the fungus Leptosphaeria maculans, anamorph: Phoma lingam (Tode ex Fr.) Desm., is one of the most damaging diseases suffered by oilseed winter rape and it causes large yield losses (Jędryczka 2007). L. maculans is a hemibiotrophic pathogen with an initial necrotrophic stage characterized by toxin (sirodesmins) production and necrotic spot formation (Fitt et al. 2006; Jindřichová et al. 2011; Kachlicki \& Jędryczka 1994; Rouxel \& Balesdent 2005). The first symptoms of blackleg can be observed at the seedling stage during autumn, but the disease develops throughout all the growth stages of the plant (Gladders \& Musa 1980).

Plants attacked by the pathogenic fungus can activate many defense mechanisms to restrict the pathogens' 
growth and/or to destroy them. Hypersensitive response (HR) under fungus infection is one of the most important defense mechanisms, and it results in both necrotization of infected tissues and protection of non-infected ones (Roussel et al. 1999). Cellular necrosis is probably a consequence of reactive oxygen species (ROS) accumulation, mainly hydrogen peroxide $\left(\mathrm{H}_{2} \mathrm{O}_{2}\right)$ and superoxide radical $\left(\mathrm{O}_{2}{ }^{-}{ }^{-}\right)$(Jindřichová et al. 2011). However, it should be stressed that ROS produced in the oxidative burst could reduce pathogen infection and also destroy the non-infected cells. Boosted production of ROS triggers increased activity of antioxidant enzymes, such as catalase (CAT), superoxide dismutase (SOD) and peroxidase (POX) (Foyer et al. 1994). All the above mentioned enzymes are involved in the defense mechanisms that control the concentration of $\mathrm{O}_{2}{ }^{-}$and $\mathrm{H}_{2} \mathrm{O}_{2}$ in the infected plants (Bowler et al. 1992).

Induction of phenolics production, constituting another defense mechanism, may be of crucial importance for the restriction of pathogenic fungus expansion. Phenylalanine ammonia-lyase (PAL) catalyzes the conversion of $L$-phenylalanine to trans-cinnamic acid that is a precursor of other phenolic compounds. It was shown that the increase in PAL activity is associated with the defense responses under pathogen attack (Kavitha \& Umesha 2008; Umesha 2006). Plant phenolics were reported to be low-molecular weight ROS scavengers. Some of them can be utilized during lignin biosynthesis, and as phytoalexins they inhibit pathogen development in infected and non-infected cells (Matern \& Kneusel 1988; Płażek et al. 2005).

The biochemical response of oilseed winter rape to blackleg at the cellular level has not been well recognized so far. To find a reliable biochemical indicator of oilseed rape resistance to blackleg, we need to find out which defense mechanisms are activated in response to L. maculans attack. In this study we present biochemical responses induced by spores of $P$. lingam in seedlings of oilseed winter rape, determined 24,48 and $72 \mathrm{~h}$ after inoculation. Analyses of the antioxidant enzymes activity (SOD, CAT, POX) and ROS level $\left(\mathrm{O}_{2}{ }^{--}\right.$and $\left.\mathrm{H}_{2} \mathrm{O}_{2}\right)$ were performed. Additionally, measurements of total pool of phenolic compounds, trans-cinnamic acid and ferulic acid were carried out. Trans-cinnamic acid was chosen as the precursor of other phenolics in the phenylpropanoid pathway, while ferulic acid was selected as a compound that could affect cell wall properties via its lignification.

\section{Materials and methods}

Plant growth conditions The experiment was carried out on seedlings of oilseed winter rape (Brassica napus L.) cv. Lisek. The seedlings were grown in plastic pots (five seedlings per pot) $15 \mathrm{~cm}$ in diameter and $18 \mathrm{~cm}$ in height. Each pot was filled with a mixture of soil, peat and sand $(2: 1: 1 \mathrm{v} / \mathrm{v} / \mathrm{v})$. The plants were grown in an air-conditioned greenhouse chamber, at $16 / 16^{\circ} \mathrm{C}\left( \pm 2^{\circ} \mathrm{C}\right)$ day/night, and $\sim 60 \%$ r.h. The plants were additionally illuminated $(12 \mathrm{~h} \mathrm{~L}: 12 \mathrm{~h} \mathrm{D})$, so that PPFD (photosynthetic photon flux density) at the leaf level was $\sim 200 \mu \mathrm{mol} \mathrm{m} \mathrm{m}^{-2} \mathrm{~s}^{-1}$.

Inoculation of cotyledons with P. lingam Sixteen dayold seedlings (stadium of two cotyledons) were inoculated with the P. lingam spores according to the method described by Jędryczka et al. (1991). To allow the spore suspension infiltrate into the intercellular space, the seedlings were punctured with a needle in the middle of each half of the cotyledon. Then each puncture site was centrally injected with $10 \mu \mathrm{l}$ of inoculum with a density of $1.5 \times 10^{7}$ spores $\mathrm{ml}^{-1}$. As a consequence each seedling had four inoculation points in which the spore suspension was administered. Control plants were injected with $10 \mu \mathrm{l}$ of sterile distilled water. Spore suspension and water were applied using a syringe with a needle. After that the seedlings were incubated in a shady place in the chamber at $18^{\circ} \mathrm{C}$ and the relative humidity was adjusted to $80 \%$. The isolate (Ph L5) (Kachlicki \& Jędryczka 1994) from the fungus $P$. lingam, used for this experiment, was obtained from the Institute of Plant Genetics of the Polish Academy of Sciences in Poznań.

Biochemical measurements and sample collection The measurements were performed $24 \mathrm{~h}, 48 \mathrm{~h}$ and $72 \mathrm{~h}$ after inoculation. Due to time-consuming procedures the histochemical analyses of $\mathrm{H}_{2} \mathrm{O}_{2}$ and $\mathrm{O}_{2}{ }^{-}$were completed $48 \mathrm{~h}, 120 \mathrm{~h}$, and $168 \mathrm{~h}$ after inoculation for $\mathrm{H}_{2} \mathrm{O}_{2}$ and after $48 \mathrm{~h}, 96 \mathrm{~h}$, and $144 \mathrm{~h}$ for $\mathrm{O}_{2}{ }^{\circ}$. Another reason for this delay was our intention to estimate the level of defense mechanisms induction associated with ROS generation in the indirectly inoculated first true leaf. CAT, non-specific peroxidase and PAL activities were recalculated for protein content, estimated according to the procedure described by Bradford (1976). 
Spectrofluorescence analysis of $\mathrm{H}_{2} \mathrm{O}_{2}$ Hydrogen peroxide content was calculated in the extracts from fresh leaves according to the procedure described by Ishikawa et al. (1993). Samples (150-200 mg of fresh weight) were homogenized in $1.5 \mathrm{ml}$ of extraction buffer $(50 \mathrm{mM}$ potassium phosphate buffer $\mathrm{pH} 7.5$, 5\% trichloroacetic acid (TCA), $1 \mathrm{mM}$ EDTA, 1\% w/v polyvinylpyrrolidone) at $4{ }^{\circ} \mathrm{C}$. The homogenate was centrifuged at $14,000 \mathrm{rpm}$ for $10 \mathrm{~min}$. The reaction mixture contained $2.5 \mathrm{ml}$ of $1.25 \mathrm{mM}$ homovanillic acid, $2.5 \mu$ of horseradish peroxidase (1380 $\mathrm{U} \mathrm{mg}^{-1}$ ) and $20 \mu \mathrm{l}$ of the buffered extract. Hydrogen peroxide was detected with a spectrofluorometer (Perkin-Elmer LS 50B, Norwalk, CT, USA). The samples were excited at $315 \mathrm{~nm}$ and the detection was carried out between 400 and $450 \mathrm{~nm}$. The slit width for both excitation and emission monochromators was adjusted to $10 \mathrm{~nm}$. Hydrogen peroxide content was expressed in $\mu$ land recalculated in relation to fresh weight. The measurements were taken in three replicates.

Activity of catalase (CAT) (E.C. 1.11.1.6) Catalase activity was estimated according to Aebi (1984). Plant material (350-500 mg of fresh weight) was homogenized in the extraction buffer $(50 \mathrm{mM}$ potassium phosphate buffer $\mathrm{pH} 7.5,1 \mathrm{mM}$ EDTA) at $4^{\circ} \mathrm{C}$. Plant extract $(100 \mu \mathrm{l})$ was added to the reaction mixture consisting of $0.3 \mathrm{ml}$ of $30 \% \mathrm{H}_{2} \mathrm{O}_{2}$ in $50 \mathrm{mM}$ potassium phosphate buffer $\mathrm{pH} 7.8$ and $1 \mathrm{mM}$ EDTA. Absorbance was analyzed at $240 \mathrm{~nm}$. Enzyme activity was recalculated assuming that absorbance drop of $\sim 0.0145$ corresponds to degradation of $1 \mu \mathrm{mol} \mathrm{H}_{2} \mathrm{O}_{2}$ within $1 \mathrm{~min}$. The measurements were taken in three replicates.

Activity of non-specific peroxidase The samples (350$500 \mathrm{mg}$ of fresh weight) were homogenized in the extraction buffer $(50 \mathrm{mM}$ potassium phosphate buffer $\mathrm{pH} 7.0,1 \mathrm{mM}$ EDTA) at $4^{\circ} \mathrm{C}$. The reaction mixture included $2 \mathrm{ml}$ of $50 \mathrm{mM}$ potassium phosphate buffer $\mathrm{pH}$ 7.8 with $1 \mathrm{mM}$ EDTA, $12 \mu \mathrm{l}$ of p-phenylenediamine, $12 \mu \mathrm{l}$ of $30 \% \mathrm{H}_{2} \mathrm{O}_{2}$ and $12 \mu \mathrm{l}$ of plant extract. Activity of non-specific peroxidase was measured spectrophotometrically at $460 \mathrm{~nm}$. Increased absorbance positively correlates with the accumulation of oxidized products of p-phenyldiamine in the presence of $\mathrm{H}_{2} \mathrm{O}_{2}$ (Bergmeyer 1965). The enzyme activity was recalculated per $1 \mathrm{mg}$ of protein and expressed as the absorbance drop within 1 min. The measurements were taken in three replicates.
Activity of superoxide dismutase (SOD) (E.C. 1.15.1.1) SOD activity was quantified according to McCord \& Fridovich (1969). The samples were homogenized in the extraction buffer $(50 \mathrm{mM}$ potassium phosphate buffer $\mathrm{pH} 7.8,10 \mathrm{mM}$ EDTA) at $4^{\circ} \mathrm{C}$. The reaction mixture consisted of $50 \mathrm{mM}$ potassium phosphate buffer $\mathrm{pH} 7.8$ with $1 \mathrm{mM}$ EDTA, buffered solution of $1 \mathrm{mM}$ cytochrome $c, 1 \mathrm{mM}$ xanthine and the plant extract. One unit was defined as the amount of enzyme necessary for $50 \%$ inhibition of cytochrome $c$ in a coupled system with xanthine and xanthine oxidase. The absorbance was measured at $550 \mathrm{~nm}$ and the enzyme activity was recalculated per $1 \mathrm{mg}$ of protein and expressed in cytochrome $c$ units. The measurements were taken in five replicates.

Detection of SOD isoforms (Mn-SOD, Cu/Zn-SOD, $\mathrm{Fe}$-SOD) Electrophoresis was performed at $4{ }^{\circ} \mathrm{C}$, $180 \mathrm{~V}$ in $13 \%$ polyacrylamide gel (Laemmli 1970). For each lane $15 \mu \mathrm{g}$ of protein extract was applied. Identification of individual SOD isoforms was carried out according to the procedure described by Beauchamp \& Fridovich (1971). After electrophoresis the gels were incubated for $30 \mathrm{~min}$ in the dark at room temperature in the staining buffer consisting of $50 \mathrm{mM}$ potassium phosphate buffer $\mathrm{pH} 7.8,1 \mathrm{mM}$ EDTA, $28 \mathrm{mM}$ TEMED, $0.03 \mathrm{mM}$ riboflavin and $2.45 \mathrm{mM}$ NBT. After that the gels were exposed to daylight until the SOD activity bands became visible. To inhibit $\mathrm{Cu} / \mathrm{Zn}$ $\mathrm{SOD}$ and $\mathrm{Fe}-\mathrm{SOD}$ isoforms the gels were stained in the buffer containing $5 \mathrm{mM} \mathrm{H}_{2} \mathrm{O}_{2}$. Selective inhibition of $\mathrm{Cu} / \mathrm{Zn}-\mathrm{SOD}$ was executed by the gel incubation in the buffer containing $3 \mathrm{mM} \mathrm{KCN}$. Mn-SOD isoform was not inhibited by either $\mathrm{H}_{2} \mathrm{O}_{2}$ or KCN.

Histochemical detection of $\mathrm{H}_{2} \mathrm{O}_{2}$ accumulation Hydrogen peroxide in leaves and cotyledons was detected according to Thordal-Christensen et al. (1997) with our modification. The leaves and cotyledons were infiltrated in darkness for $15 \mathrm{~min}$ under pressure of $0.8 \mathrm{MPa}$ with 3,3'-diaminobenzidine (DAB) solution. $\mathrm{DAB}$ aqueous solution was prepared using $1 \mathrm{mg}$ DAB per $1 \mathrm{ml} \mathrm{H}_{2} \mathrm{O}$, and $\mathrm{pH}$ was adjusted with $0.1 \mathrm{M} \mathrm{HCl}$ to 3.8. To remove chlorophyll from tissues, the leaves and cotyledons were rinsed several times with hot $\left(60^{\circ} \mathrm{C}\right)$ ethanol $(96 \%)$ at low light conditions. The colored spots of $\mathrm{H}_{2} \mathrm{O}_{2}$ accumulation, which appeared on the leaves and cotyledons, were scanned. 
Histochemical identification of superoxide radical $\left(\mathrm{O}_{2}{ }^{-}\right)$Dye-based identification of superoxide radical $\left(\mathrm{O}_{2}{ }^{-}\right)$in the leaves and cotyledons was performed employing the method described by Doke \& Ohashi (1988). Plant material was infiltrated in darkness for 15 min under pressure of $0.8 \mathrm{MPa}$ with a solution containing $0.5 \%(\mathrm{w} / \mathrm{v})$ nitroblue tetrazolium (NBT), $10 \mathrm{mM}$ potassium phosphate buffer $\mathrm{pH} 7.0$ and $0.005 \%(\mathrm{w} / \mathrm{v})$ Triton X-100. After that the plant material was exposed to light for $15 \mathrm{~min}$. The leaves and cotyledons were rinsed several times with hot $\left(60^{\circ} \mathrm{C}\right)$ ethanol (96\%) to remove chlorophyll from plant tissue. The colored spots (dark blue) of superoxide radical accumulation in the leaves and cotyledons were scanned.

Activity of L-phenylalanine ammonia-lyase (PAL) (E.C. 4.3.1.5.) Measurement of PAL activity was carried out according to the method described by Peltonen \& Karjalainen (1995). Extraction procedure was performed at $+4^{\circ} \mathrm{C}$. The samples (100-200 $\mathrm{mg}$ of fresh weight) were homogenized in the extraction buffer (50 mM Tris-HCl pH 8.5, 14.4 mM 2mercaptoethanol, $5 \% \mathrm{w} / \mathrm{v}$ polyvinylpyrrolidone). The plant extract $(500 \mu \mathrm{l})$ was added to the reaction mixture of $2.5 \mathrm{ml}$ of $0.2 \% \mathrm{~L}$-phenylalanine in $50 \mathrm{mM}$ Tris- $\mathrm{HCl}$ $(\mathrm{pH} 8.5)$. The reaction mixture was then incubated for $24 \mathrm{~h}$ at $38^{\circ} \mathrm{C}$. After that the absorbance at $290 \mathrm{~nm}$ was measured. The enzyme activity was expressed as $\mu \mathrm{mol}$ of cinnamic acid produced within $1 \mathrm{~min}$ per $1 \mathrm{mg}$ of protein. The measurements were taken in five replicates.

Total phenolics analysis The plant material for the total phenolics and trans-cinnamic acid and ferulic acid measurements was homogenized in $80 \%$ ethanol. The homogenate was centrifuged at $13,000 \mathrm{rpm}$ for $15 \mathrm{~min}$ at $+4^{\circ} \mathrm{C}$. Total concentration of phenolics was determined using the Folin-Ciocalteu method of Singleton \& Rossi (1965). Supernatant $(0.1 \mathrm{ml})$ was added to the measurement solution consisting of $0.9 \mathrm{ml}$ of distilled water, $0.5 \mathrm{ml}$ of $25 \% \mathrm{Na}_{2} \mathrm{CO}_{3}$ and $0.125 \mathrm{ml}$ of Folin-Ciocalteu reagent which was previously diluted two times with distilled water. The absorbance was measured at $760 \mathrm{~nm}$. Chlorogenic acid was used as a standard. The measurements for each genotype were taken in five replicates.

Trans-cinnamic and ferulic acid content Before analysis the chlorophyll present in the supernatant was removed by several extractions with hexane, until no green color was visible. The trans-cinnamic and ferulic acid were separated by silica gel thin-layer chromatography (TLC, silica gel $60 \mathrm{~F}_{254} 0.25 \mathrm{~mm}$ thick, Merck \& Co., Inc., Rockville, MD, USA). The mixture of benzene, acetic acid and $\mathrm{MeOH}(45: 8: 4 \mathrm{v} / \mathrm{v} / \mathrm{v})$ was used as a developing solvent. Phenolics were located on the TLC plates as spots under UV radiation. They were scraped off the silica gel and eluted with $2 \mathrm{ml}$ of $80 \%$ ethanol.

The concentration of phenolics was determined with a spectrofluorometer (Perkin-Elmer LS 50B). To determine ferulic acid content the samples were excited at $300 \mathrm{~nm}$ and the fluorescence emission was detected at $434 \mathrm{~nm}$. The slit widths for both excitation and emission monochromators were adjusted to $10 \mathrm{~nm}$.

In order to determine trans-cinnamic acid concentration the samples were excited at $290 \mathrm{~nm}$ and the fluorescence emission was detected at $320-350 \mathrm{~nm}$. The slit widths for both excitation and emission monochromators were adjusted to $15 \mathrm{~nm}$. The measurements of phenolics and both acids were taken in five replicates.

Statistical analysis The results were statistically evaluated using the Statistica software for Windows, version 10 . The data were analyzed using Student's t-test at $P=0.05$. Statistically significant differences are marked on the Figures with asterisks.

\section{Results}

Twenty-four hours after inoculation, hydrogen peroxide content was very close to the control. Maximum concentration of $\mathrm{H}_{2} \mathrm{O}_{2}$ was detected $48 \mathrm{~h}$ after inoculation and was significantly higher than in the control seedlings. A decrease in $\mathrm{H}_{2} \mathrm{O}_{2}$ level was found $72 \mathrm{~h}$ after inoculation and was slightly higher than that observed in the control plants (Fig. 1a). Hydrogen peroxide level in the control seedlings was relatively constant, and the lowest value was perceived $72 \mathrm{~h}$ after water inoculation.

Figure $1 \mathrm{~b}$ shows the changes in CAT activity following the inoculation in relation to the control seedlings. In general, pathogen-inoculated seedlings exhibited higher CAT activity than the control ones. However, statistically significant differences were 

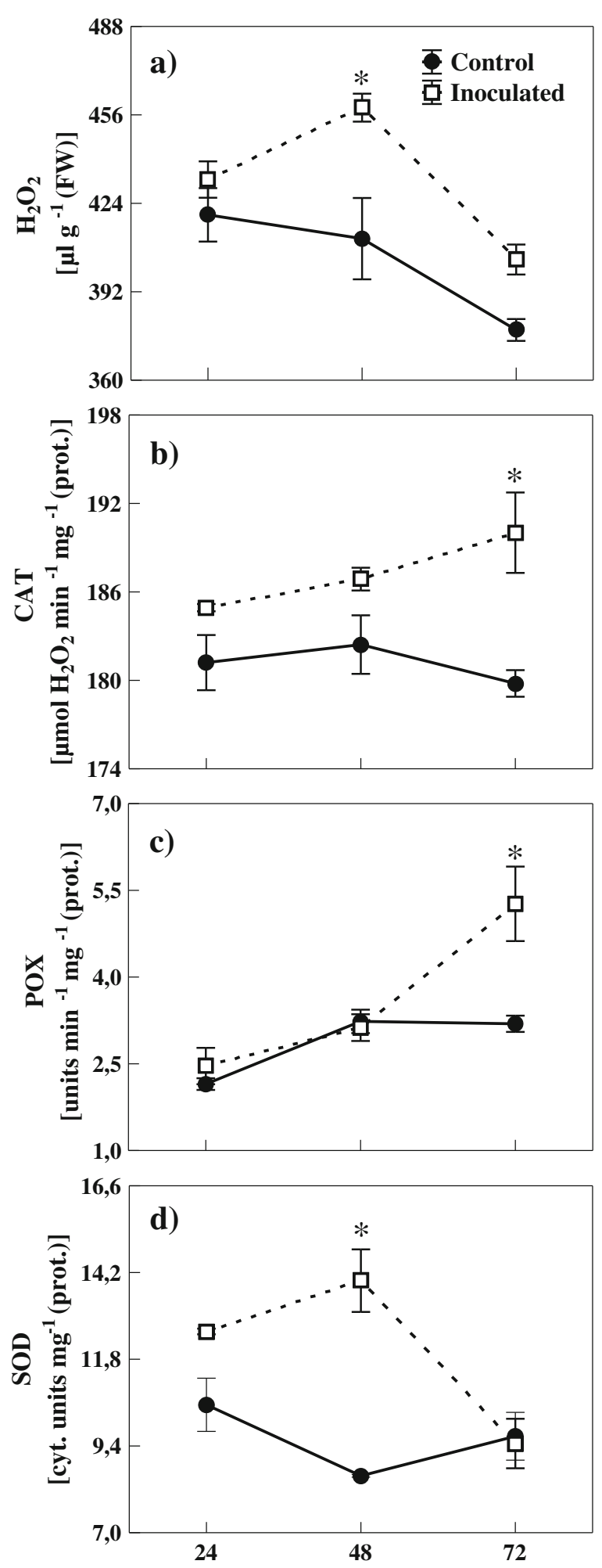

Hours after inoculation
Fig. 1 Change in hydrogen peroxide level (a) and the activity of antioxidant enzymes CAT (b), POX (c), and SOD (d) observed 24, 48 and $72 \mathrm{~h}$ after inoculation. Each point represents the mean \pm standard error. ${ }^{*} \mathrm{P}<0.05 v s$ control, Student's t-test

observed only $72 \mathrm{~h}$ after inoculation. Similarly, significant increase in the activity of non-specific peroxidise (POX) was observed after this time (Fig. 1c). Twentyfour and $48 \mathrm{~h}$ after inoculation POX activity in pathogen-inoculated seedlings was the same as in the controls, whereas the activity of superoxide dismutase was significantly higher $48 \mathrm{~h}$ after inoculation (Fig. 1d). SOD activity 24 and $72 \mathrm{~h}$ after inoculation was the same as or very similar to the control seedlings.

SOD isoforms were identified using different inhibitors (Fig. 2). Native polyacrylamide gel electrophoresis and staining revealed the presence of the manganese isoform Mn-SOD (not inhibited by either $\mathrm{H}_{2} \mathrm{O}_{2}$ or $\mathrm{KCN}$ ), two isoforms of $\mathrm{Zn} / \mathrm{Cu}-\mathrm{SODI}$ and $\mathrm{Zn} / \mathrm{Cu}-$ SODII (activity of both isoforms inhibited by $5 \mathrm{mM}$ $\mathrm{H}_{2} \mathrm{O}_{2}$ or $3 \mathrm{mM} \mathrm{KCN}$ ). The iron isoform Fe-SOD (activity inhibited by $5 \mathrm{mM} \mathrm{H}_{2} \mathrm{O}_{2}$ ) was detected. In the case of zinc-copper isoform ( $\mathrm{Zn} / \mathrm{Cu}-\mathrm{SODI})$, two or three additional sub-isoforms were detected (C48, I72). Seventy-two hours after inoculation two subisoforms of $\mathrm{Zn} / \mathrm{Cu}$-SODI were identified in the study plants (the third band was barely visible), and only one band was visible in the control plants. Forty-eight hours after inoculation one $\mathrm{Zn} / \mathrm{Cu}$-SODI isoform was visible in the inoculated plants and three in the control seedlings. In the course of pathogenesis SOD isoforms did not exhibit significant changes in activity (similar band intensity) in the control and inoculated seedlings (Fig. 2). However, $\mathrm{Zn} / \mathrm{Cu}$-SODII bands evaluated $24 \mathrm{~h}$ after inoculation exhibited slightly higher intensity than those observed for control plants. Similarly, $48 \mathrm{~h}$ after inoculation $\mathrm{Zn} / \mathrm{Cu}$-SODI bands exhibited higher intensity than those observed for control plants (three isoforms). Inversely, after $72 \mathrm{~h}$ the intensity of $\mathrm{Zn} /$ $\mathrm{Cu}$-SODI bands was lower in the inoculated samples.

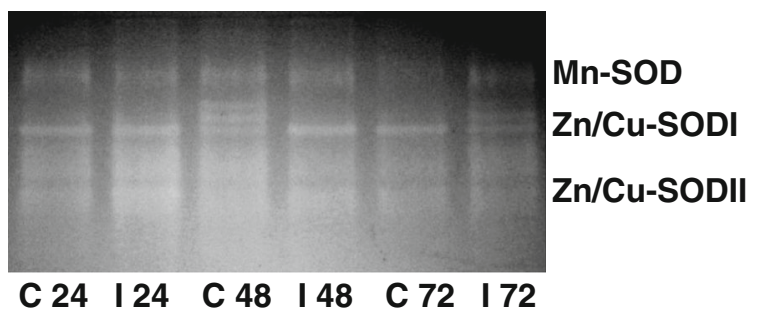

Fig. 2 Superoxide dismutase (SOD) isoforms of control (C) and inoculated (I) plants observed 24, 48 and $72 \mathrm{~h}$ after inoculation 
Fig. 3 Histochemical identification of superoxide radicals $\left(\mathrm{O}_{2}{ }^{--}\right)$in the cotyledons and leaves carried out 48,96 and $144 \mathrm{~h}$ after inoculation

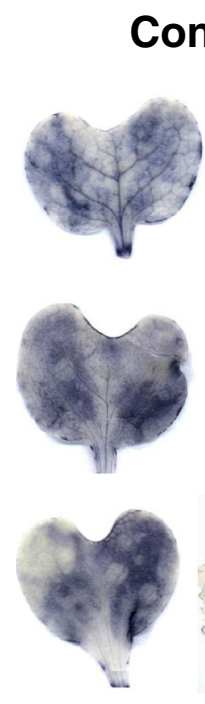

Control
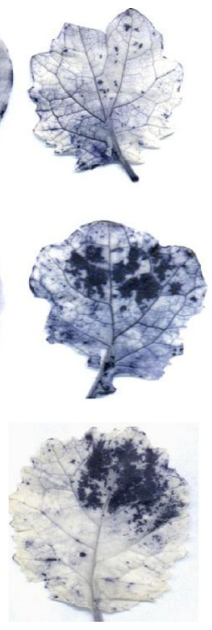

Inoculated

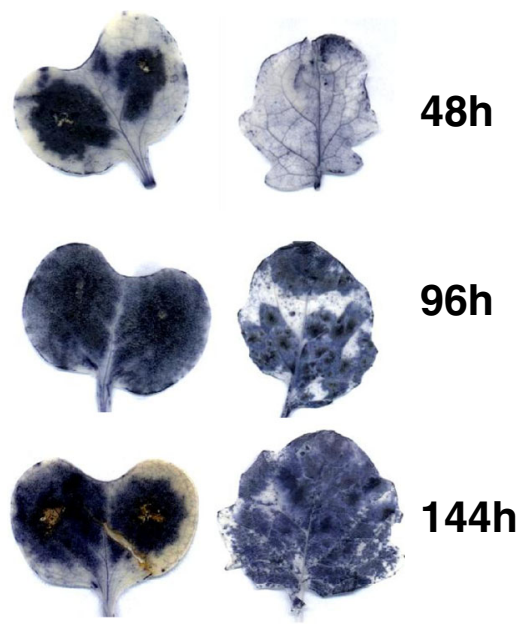

Histochemical assay of the leaves and cotyledons revealed higher content of $\mathrm{O}_{2}{ }^{--}$in the seedlings inoculated with the pathogen (Fig. 3). In cotyledons, $48 \mathrm{~h}$ following inoculation, local colored spots (dark blue) encircled the areas of superoxide radical accumulation. After $96 \mathrm{~h}$ and $144 \mathrm{~h}$ the whole inoculated cotyledon exhibited a high level of $\mathrm{O}_{2}{ }^{\circ-}$. Similarly, $96 \mathrm{~h}$ and $144 \mathrm{~h}$ after inoculation, elevated accumulation of $\mathrm{O}_{2}{ }^{--}$, manifested as dark blue spots, was discernible in indirectly inoculated true leaves. It should be stressed here that histochemical estimation of $\mathrm{O}_{2}{ }^{--}$is very sensitive to mechanical injuries. In our experiment, the leaves were punctured with a needle used for inoculation; hence the accumulation of superoxide radical was observed even in control plants which were water inoculated (Fig. 3).

The analysis revealed plant tissue accumulation of $\mathrm{H}_{2} \mathrm{O}_{2}$ after inoculation (Fig. 4). However, intensity of $\mathrm{H}_{2} \mathrm{O}_{2}$ generation was higher in the cotyledons than in indirectly inoculated true leaves. Forty-eight hours after inoculation, $\mathrm{H}_{2} \mathrm{O}_{2}$ content was detected as local dark brown spots on the cotyledons and after $120 \mathrm{~h}$ its concentration rose in the cotyledons and partly in the first true leaf. Then, $168 \mathrm{~h}$ later, a higher content of $\mathrm{H}_{2} \mathrm{O}_{2}$ was detected in both whole cotyledons and in the first true leaf in comparison to the control plants. The control plants exhibited low $\mathrm{H}_{2} \mathrm{O}_{2}$ accumulation 48 and $120 \mathrm{~h}$ after water inoculation. Hydrogen peroxide content rose in the cotyledons of the control plants $168 \mathrm{~h}$ after water inoculation, probably as a consequence of oxidative stress induced by leaf aging and mechanical injury during the analysis.
Figure 5a shows significant growth in PAL activity $48 \mathrm{~h}$ (maximum increase) and $72 \mathrm{~h}$ after inoculation in comparison with the control plants. Twenty-four hours after inoculation $L$-phenylalanine ammonia-lyase activity was the same as for control seedlings, in which it was relatively constant. The highest content of transcinnamic acid was detected $24 \mathrm{~h}$ following the pathogen inoculation (Fig. 5b). Cinnamic acid level 48 and $72 \mathrm{~h}$ after inoculation was similar to the control. In contrast, a statistically significant increase in ferulic acid concentration was observed $48 \mathrm{~h}$ after pathogen inoculation (Fig. 5c). Figure $5 \mathrm{~d}$ presents changes in the total content of soluble phenolics. A significant boost in the phenolics content was noticed $24 \mathrm{~h}$ after inoculation. The subsequent hours of pathogenesis showed a reduction in the total content of phenolic compounds to the level observed in the control seedlings (48 h, $72 \mathrm{~h}$ ).

\section{Discussion}

Plants activate certain defense mechanisms in response to a pathogen attack, including oxygen burst connected with the generation of reactive oxygen species, mainly superoxide radicals $\left(\mathrm{O}_{2}{ }^{-{ }^{-}}\right)$and/or hydrogen peroxide $\left(\mathrm{H}_{2} \mathrm{O}_{2}\right)$. However, ROS are able to destroy both pathogen cells and host cells. We have proved the virulence of $\mathrm{Ph} \mathrm{L} 5$ isolate in relation to cv. Lisek. Increased $\mathrm{O}_{2}{ }^{--}$ accumulation around the inoculated areas was found in the cotyledons of this oilseed winter rape variety $48 \mathrm{~h}$ after inoculation with P. lingam spores (Fig. 3). Moreover, $96 \mathrm{~h}$ later, a high level of $\mathrm{O}_{2}{ }^{-}$spread over 
Fig. 4 Dye-based detection of $\mathrm{H}_{2} \mathrm{O}_{2}$ accumulation in the cotyledons and leaves carried out 48,120 and $168 \mathrm{~h}$ after inoculation

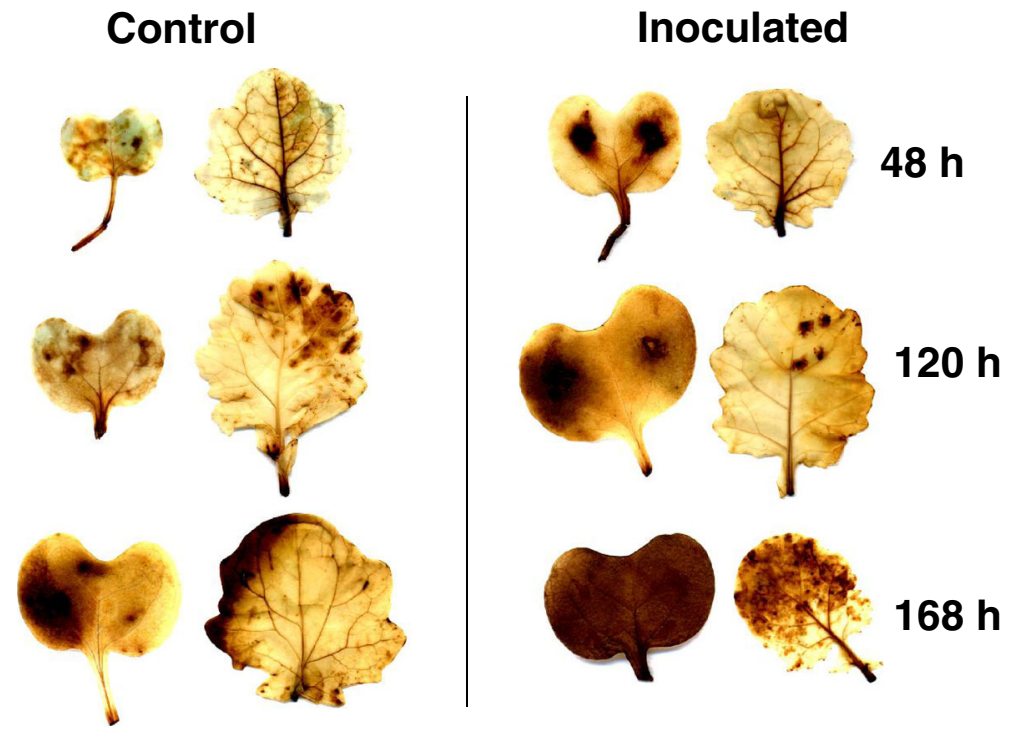

all the cotyledons and leaves. Gawlik \& Wojcik (1997) reported $\mathrm{O}_{2}{ }^{--}$overproduction in bean leaves $3 \mathrm{~h}$ after inoculation with the spores of B. cinerea and B. fabae. In the same experiment they discovered that the superoxide radical level was barely enhanced in places distant from the inoculation site. Significant participation of reactive oxygen species in plant adaptation to biotic stresses evoked by pathogens was also discussed by others (Kondo et al. 1993; Libik-Konieczny et al. 2011; Torres 2010). Our experiment confirmed intensified accumulation of $\mathrm{H}_{2} \mathrm{O}_{2}$ in rape tissues in the response to inoculation with P. lingam (Fig. 4). Hydrogen peroxide can be formed from superoxide radical as a result of the disproportional reaction catalyzed by superoxide dismutase. It has already been proved that high $\mathrm{H}_{2} \mathrm{O}_{2}$ content increases resistance to a pathogen (Barna et al. 2012). Elevated $\mathrm{H}_{2} \mathrm{O}_{2}$ level is frequently observed during pathogen infection (Bowler \& Fluhr 2000; Lee et al. 1999; Neill et al. 2002). Additionally, in the course of pathogenesis, $\mathrm{H}_{2} \mathrm{O}_{2}$ molecules participate in the signal transduction and in this way can initiate phytoalexin production, which in turn inhibits the pathogen development (Kuźniak \& Urbanek 2000). Heightened concentration of $\mathrm{H}_{2} \mathrm{O}_{2}$ and superoxide radical in indirectly inoculated first true leaves may suggest rather a systemic defense response.

It is well known that $\mathrm{O}_{2}{ }^{--}$and $\mathrm{H}_{2} \mathrm{O}_{2}$ production accompany the hypersensitive response (HR) that improves resistance to the blackleg. It was shown that the $\mathrm{HR}$ in the cotyledons of $B$. napus can be induced by inoculation with an avirulent isolate of $L$. maculans or an elicitin (cryptogein) which can mimic the effect of an avirulent isolate of L. maculans (Roussel et al. 1999). Plant interaction with the avirulent isolate can lead to a more rapid response to infection and can provide improved protection during subsequent interactions with virulent pathogens (Kuc 1987). Jędryczka et al. (1991) reported HR in oilseed winter rape treated with $P$. lingam toxins. However, it should be mentioned that while HR limits biotrophs, the necrotrophs can profit from HR-related necroses. Since L. maculans can be considered a necrotroph during early stages of infection, the necrosis caused by ROS overproduction can accelerate cell death. Therefore, the necroses can spread as a result of HR, which is a form of programmed cell death (PCD), or following phytotoxicity of fungal toxins.

In the present study, the spectrophotometric measurements, in contrast to PAGE analysis, revealed enhanced SOD activity $48 \mathrm{~h}$ after inoculation, which may be considered an early defense mechanism (Fig. 1d). Jindřichová et al. (2011) showed elevated activity of peroxidases (guaiacol and ascorbate) and superoxide dismutase in both L. maculans-infected and elicitortreated cotyledons of B. napus. Enhanced activities of antioxidant enzymes, such as catalase, non-specific peroxidase and superoxide dismutase, are frequently observed as response to ROS generation (Barna et al. 2012; Libik-Konieczny et al. 2011). In this experiment reduced SOD activity $72 \mathrm{~h}$ after inoculation was balanced by higher activity of other enzymes, i.e., catalase (Fig. 1b) and non-specific peroxidase (Fig. 1c). 

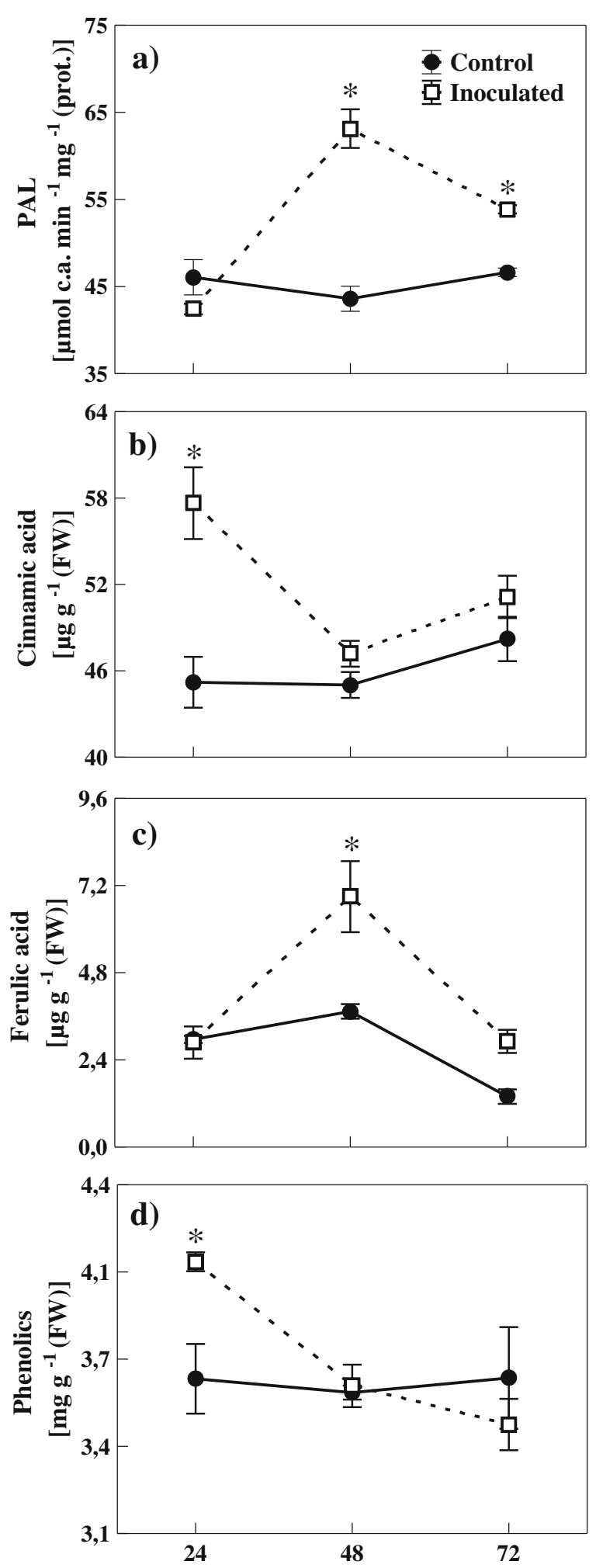

Hours after inoculation
Fig. 5 Change in PAL activity (a), cinnamic acid (b), ferulic acid (c), and total phenolics content (d) observed 24, 48 and $72 \mathrm{~h}$ after inoculation. Each point represents the mean \pm standard error. $* \mathrm{P}<0.05 v s$ control, Student's t-test

Increased activity of phenylalanine ammonia-lyase, a crucial enzyme in the synthesis of phenolic compounds (Sanchez-Ballesta et al. 2000), was observed in our study 48 and $72 \mathrm{~h}$ after inoculation. Similar responses to a pathogen attack were found in other experiments (Ishihara et al. 1999; Shadle et al. 2003). It can be suggested that low PAL activity $24 \mathrm{~h}$ after inoculation is due to phenolic compounds accumulation (high phenolics content including trans-cinnamic acid), exceeding their utilization possibilities. In the course of pathogenesis, low phenolics content may reflect their utilization in the defense mechanisms, e.g. cell wall lignification. Elevated content of ferulic acid, observed $48 \mathrm{~h}$ after inoculation, could be the result of its possible function in cell growth regulation, through ester-linked to cell wall polysaccharides (Fry 1979, 1982). This fact suggests that triggering the production of ferulic acid may contribute to making the cell walls be less extensible and to form a barrier to pathogen penetration. PAL is considered a key enzyme in synthesis of other plant phenolics, e.g. salicylic acid, an important signaling molecule in plant defense response to pathogens (Rivas-San Vicente \& Plasencia 2011). However, it was shown that resistance in the A. thaliana $-L$. maculans pathosystem is independent of salicylic acid signaling (Bohman et al. 2004). El Hadrami et al. (2010) proved the importance of the phenolic compounds in the defense mechanism in canola cultivars challenged with L. maculans and L. biglobosa.

In summary: Our results have proved the virulence of the Ph L5 isolate towards cv. Lisek. A boost in total phenolic content including trans-cinnamic acid was observed $24 \mathrm{~h}$ after inoculation. High activity of PAL could be another marker of the defense mechanisms, despite the fact that it was not accompanied by the growth in phenolics content, which was probably rapidly exhausted during $P$. lingam inoculation. Reduced phenolics content was balanced by higher activity of SOD, CAT and non-specific peroxidases. Elevated activity of these enzymes was a response to ROS overproduction. ROS accumulation in indirectly inoculated first true leaves may constitute evidence of a systemic defense response. The results presented here are the first step towards finding reliable biochemical indicators of blackleg, caused by the P. lingam infection. In order to achieve this goal, similar studies should be 
performed for other oilseed rape genotypes that differ in resistance to $P$. lingam phytotoxins.

Acknowledgments The authors thank Assoc. Prof. M. Jędryczka from the Institute of Plant Genetics PAS in Poznan for providing the isolate (Ph15) of the fungus Phoma lingam and for useful tips concerning inoculation techniques and culture of the pathogen isolates.

Open Access This article is distributed under the terms of the Creative Commons Attribution License which permits any use, distribution, and reproduction in any medium, provided the original author(s) and the source are credited.

\section{References}

Aebi, H. (1984). Catalase in vitro. In: B. J. William (Ed.) Methods in Enzymology, 105, 121-126.

Barna, B., Fodor, J., Harrach, B. D., Pogány, M., \& Király, Z. (2012). The Janus face of reactive oxygen species in resistance and susceptibility of plants to necrotrophic and biotrophic pathogens. Plant Physiology and Biochemistry, $59,37-43$

Beauchamp, C., \& Fridovich, I. (1971). Superoxide dismutase: improved assays and an assay applicable to acrylamide gels. Analytical Biochemistry, 44, 276-287.

Bergmeyer, H. U. (Ed.). (1965). Methods of enzymatic analysis. New York, NY: Academic Press.

Bohman, S., Staal, J., Thomma, B. P. H. J., Wang, M., \& Dixelius, C. (2004). Characterisation of an ArabidopsisLeptosphaeria maculans pathosystem: resistance partially requires camalexin biosynthesis and is independent of salicylic acid, ethylene and jasmonic acid signaling. The Plant Journal, 37, 9-20.

Bowler, C., \& Fluhr, R. (2000). The role of calcium and activated oxygens as signals for controlling cross-tolerance. Trends in Plant Science, 5, 241-246.

Bowler, C., Van Montagu, M., \& Inzé, D. (1992). Superoxide dismutase and stress tolerance. Annual Review of Plant Physiology and Plant Molecular Biology, 43, 83-116.

Bradford, M. M. (1976). A rapid and sensitive method for the quantitation of microgram quantities of protein utilizing the principle of protein-dye binding. Analytical Biochemistry, $72,248-254$.

Doke, N., \& Ohashi, Y. (1988). Involvement of an $\mathrm{O}^{2 \bullet-}$ generating system in the induction of necrotic lesions on tobacco leaves infected with tobacco mosaic virus. Physiological and Molecular Plant Pathology, 32, 163-175.

El Hadrami, A., Fernando, W. G. D., \& Daayf, F. (2010). Variations in relative humidity modulate Leptosphaeria spp. pathogenicity and interfere with canola mechanisms of defence. European Journal of Plant Pathology, 126, 187-202.

Fitt, B. D. L., Brun, H., Barbetti, M. J., \& Rimmer, S. R. (2006). World-wide importance of phoma stem canker (Leptosphaeria maculans and L. biglobosa) on oilseed rape (Brassica napus). European Journal of Plant Pathology, 114, 3-15.

Foyer, C. H., Descourvières, P., \& Kunert, K. J. (1994). Protection against oxygen radicals: an important defence mechanism studied in transgenic plants. Plant, Cell \& Environment, 17, 507-523.

Fry, S. C. (1979). Phenolic components of the primary cell wall and their possible role in the hormonal regulation of growth. Planta, 146, 343-351.

Fry, S. C. (1982). Phenolic components of the primary cell wall. Biochemical Journal, 203, 493-504.

Gawlik, U., \& Wojcik, W. (1997). Some aspects of induced plant resistance for fungal pathogens. Advances of Agricultural Sciences Problem Issues, 3, 21-29.

Gladders, P., \& Musa, T. M. (1980). Observations on the epidemiology of Leptosphaeria maculans stem canker in winter oilseed rape. Plant Pathology, 29, 28-37.

Ishihara, A., Ohtsu, Y., \& Iwamura, H. (1999). Induction of biosynthetic enzymes for avenanthramides in elicitortreated oat leaves. Planta, 208, 512-518.

Ishikawa, T., Takeda, T., Shigeoka, S., Hirayama, O., \& Mitsunaga, T. (1993). Hydrogen peroxide generation in organelles of Euglena gracilis. Phytochemistry, 33, 1297-1299.

Jędryczka, M. (2007). Epidemiology and damage caused by stem canker of oilseed rape in Poland. Phytopathologica Polonica, 45, 73-75.

Jędryczka, M., Starzycki, M., Lewartowska, E., \& Frencel, I. (1991). Studies of in vitro toxic effect of Phoma lingam (Tode ex Fr.) Desm. culture filtrate on winter oilseed rape (Brassica napus L.) haploid embryos. International Organization for Biological and Integrated Control of Noxious Animals and Plants - West Palearctic Regional Section Bulletin, 14, 196-204.

Jindřichová, B., Fodor, J., Šindelářová, M., Burketová, L., \& Valentová, O. (2011). Role of hydrogen peroxide and antioxidant enzymes in the interaction between a hemibiotrophic fungal pathogen, Leptosphaeria maculans, and oilseed rape. Environmental \& Experimental Botany, 72, 149-156.

Kachlicki, P., \& Jędryczka, M. (1994). Properties of Phoma lingam (Tode ex Fr.) Desm. isolates from Poland. II. Secondary metabolites production. Phytopathologica Polonica, 7, 81-86.

Kavitha, R., \& Umesha, S. (2008). Regulation of defense-related enzymes associated with bacterial spot resistance in tomato. Phytoparasitica, 36, 144-159.

Kondo, Y., Hanawa, F., Miyazwa, T., \& Mizutani, J. (1993). Detection of rapid and transient generation of activated oxygen and phospholipid hydroperoxide in soybean after treatment with fungal elicitor by chemiluminescence assay. In: B. Fritig \& M. Legrand (Eds.) Mechanism of plant defence responses, (pp. 148-151). Dordrecht, the Netherlands: Kluwer Academic Publishers.

Kuc, J. (1987). Plant immunization and its applicability for disease control. In: I. Chet (Ed.) Innovative approaches to plant disease control, (pp. 255-274). New York, NY: John Wiley and Sons.

Kuźniak, E., \& Urbanek, H. (2000). The involvement of hydrogen peroxide in plant responses to stresses. Acta Physiologiae Plantarum, 22, 195-203.

Laemmli, U. K. (1970). Cleavage of structural proteins during the assembly of the head of bacteriophage T4. Nature, 227, 680-685.

Lee, S., Choi, H., Suh, S., Doo, I., Oh, K., Choi, E. J., et al. (1999). Oligogalacturonic acid and chitosan reduce stomatal aperture by inducing the evolution of reactive oxygen 
species from guard cells of tomato and Commelina communis. Plant Physiology, 121, 147-152.

Libik-Konieczny, M., Surówka, E., Kuźniak, E., Nosek, M., \& Miszalski, Z. (2011). Effects of Botrytis cinerea and Pseudomonas syringae infection on the antioxidant profile of Mesembryanthemum crystallinum C3/CAM intermediate plant. Journal of Plant Physiology, 168, 1052-1059.

Matern, U., \& Kneusel, R. E. (1988). Phenolic compounds in plant disease resistance. Phytoparasitica, 16, 153-170.

McCord, J. M., \& Fridovich, I. (1969). Superoxide dismutase: an enzymic function for erythrocuprein (hemocuprein). Journal of Biological Chemistry, 244, 6049-6055.

Neill, S. J., Desikan, R., Clarke, A., Hurst, R. D., \& Hancock, J. T. (2002). Hydrogen peroxide and nitric oxide as signalling molecules in plants. Journal of Experimental Botany, 53, 1237-1247.

Peltonen, S., \& Karjalainen, R. (1995). Phenylalanine ammonialyase activity in barley after infection with Bipolaris sorokiniana or treatment with its purified xylanase. Journal of Phytopathology, 143, 239-245.

Płażek, A., Hura, K., \& Żur, I. (2005). Influence of chitosan, pectinase and fungal metabolites on activation of phenylpropanoid pathway and antioxidant activity in oilseed rape callus. Acta Physiologiae Plantarum, 27, 95-102.

Rivas-San Vicente, M., \& Plasencia, J. (2011). Salicylic acid beyond defence: its role in plant growth and development. Journal of Experimental Botany, 62, 3321-3338.

Roussel, S., Nicole, M., Lopez, F., Ricci, P., Geiger, J. P., Renard, M., et al. (1999). Leptosphaeria maculans and cryptogein induce similar vascular responses in tissues undergoing the hypersensitive reaction in Brassica napus. Plant Science, 144, 17-28.

Rouxel, T., \& Balesdent, M. H. (2005). The stem canker (blackleg) fungus, Leptosphaeria maculans, enters the genomic era. Molecular Plant Pathology, 6, 225-241.

Sanchez-Ballesta, M. T., Lefuente, M. T., Zacarias, L., \& Granell, A. (2000). Involvement of phenylalanine ammonia-lyase in the response of Fortune mandarin fruits to cold temperature. Physiologia Plantarum, 108, 382-389.

Shadle, G. L., Wesley, S. V., Korth, K. L., Chen, F., Lamb, C., \& Dixon, R. A. (2003). Phenylpropanoid compounds and disease resistance in transgenic tobacco with altered expression of $L$ phenylalanine ammonia-lyase. Phytochemistry, 64, 153-161.

Singleton, V. S., \& Rossi, J. A., Jr. (1965). Colorimetry of total phenolics with phosphomolybdic-phosphotungstic acid reagents. American Journal of Enology and Viticulture, 16, 144-158.

Thordal-Christensen, H., Zhang, Z., Wei, Y., \& Collinge, D. B. (1997). Subcellular localization of $\mathrm{H}_{2} \mathrm{O}_{2}$ in plants. $\mathrm{H}_{2} \mathrm{O}_{2}$ accumulation in papillae and hypersensitive response during the barley-powdery mildew interaction. The Plant Journal, 11, 1187-1194.

Torres, M. A. (2010). ROS in biotic interactions. Physiologia Plantarum, 138, 414-429.

Umesha, S. (2006). Phenylalanine ammonia lyase activity in tomato seedlings and its relationship to bacterial canker disease resistance. Phytoparasitica, 34, 68-71. 